\title{
FERRO, Marc. A colonização explicada a todos. São Paulo: Editora Unesp, 2017. 190 p.
}

\author{
Thiago Henrique Sampaio* \\ *Universidade Estadual Paulista - Assis, SP, Brasil \\ Mestrando em História (bolsista CNPq) \\ thiago.sampaio92@gmail.com
}




\section{Para compreender a colonização: dilemas do passado na atualidade}

Marc Ferro é um importante historiador francês da terceira geração dos Annales e foi diretor da École des Hautes Études en Sciences Sociales, especialista na história da Rússia e da URSS e na relação história e cinema. Ele não ficou restrito apenas a essas áreas de pesquisa, como um grande historiador, e em diversas obras se aventurou a analisar a problemática da colonização. Suas obras mais conhecidas nessa temática são História das colonizações (Ferro, 1996) e O livro negro do colonialismo (Ferro, 2004).

A obra A colonização explicada a todos faz parte de uma série de livros que buscam atingir o grande público de forma meticulosa e didática. Outros autores já realizaram esse feito, como Le Goff nas obras A Europa explicada aos jovens (Le Goff, 2007a) e A Idade Média explicada aos meus filhos (Le Goff, 2007b) ou Michel Vovelle (2005) com sua A Revolução Francesa explicada à minha neta. Esses grandes pesquisadores ao quererem produzir obras claras, dinâmicas e com uma leitura agradável aos leigos da área de história, mostram ao público em geral que a história não é algo de difícil acesso ou restrito a uma camada letrada em nossa sociedade.

O livro de Marc Ferro divide-se em oito capítulos e uma lista de referências que incluem filmes sobre as temáticas abordadas. Ao trazer para o público leitor uma lista cinematográfica o autor apresenta uma defesa em favor do cinema para a produção dos conhecimentos históricos e como uma forma de se pensar as pesquisas e o ensino de história.

No primeiro capítulo, “Colônias para quê?", Marc Ferro define o que seria a colonização e as diferenças das práticas coloniais do século XVI e XIX. Nessa primeira parte, $o$ autor versa sobre sua forma de trabalho ao longo da obra através de perguntas e respostas claras, didáticas e objetivas.

Marc Ferro deixa claro que ao longo da história humana sempre existiram colônias, mas a partir do século XVI essa dinâmica colonizadora começou a se alterar e intensificar. São mostradas as diferenças nas práticas coloniais entre os pioneiros das Grandes Navegações, Portugal e Espanha, e a entrada da França e Inglaterra em busca de territórios. As religiões e companhias de catequização tiveram um papel fundamental nesse primeiro momento de expansão colonial. 
O autor chama a atenção nesse capítulo em dois momentos. No primeiro, para salientar o papel da violência nas práticas coloniais como o uso da escravidão e as formas de assimilação das populações nativas ao Estado colonial. No segundo, para quebrar a ideia de que a colonização só aconteceu em outros continentes e de forma descontinuada ao território da metrópole, e para isso ele disserta sobre o caso do império russo.

No capítulo seguinte, "As independências dos colonos", Marc Ferro analisa o papel dos colonos para a independência dos territórios colonizados. $\mathrm{O}$ autor faz suas interpretações a partir das independências ocorridas na América e examina os domínios coloniais ingleses (Canadá, Austrália e Nova Zelândia).

É chamada a atenção para o que acontece com a população nativa após os processos de independência e como ela é tratada pelas novas administrações das localidades. No caso dos Estados Unidos, o autor examina que isso ocorreu de forma dramática e os indígenas foram considerados como um obstáculo para a expansão territorial do novo país. Além disso, sua população negra foi tratada como escrava até a Guerra de Secessão (1861-1865) e só teve seus direitos de cidadania plena adquirida no início da segunda metade do século XX. Esse fenômeno da relação da nova administração com as populações locais é notado também pelo autor no caso da Austrália com os seus aborígenes.

No terceiro capítulo, "Os objetivos do Imperialismo", Marc Ferro aprecia a revisão da política colonial europeia após os movimentos de independência da América e as consequências da Revolução Industrial para essa nova etapa da expansão territorial que ocorreu no século XIX.

Marc Ferro aponta que os principais países afetados com as independências na América e com o novo processo de expansão territorial em finais de XIX são Espanha e Portugal, que não conseguiram acompanhar as demais potências europeias no processo de industrialização e desenvolvimento.

A nova dominação colonial do final do Oitocentos é acompanhada com ideias de desigualdade entre os diferentes povos, por isso a colonização seria justificada como um "dever" do europeu de transmitir a "civilidade" para outras sociedades. Assim, diversos discursos científicos buscaram amenizar o caráter colonizador europeu em outras partes do mundo. A imposição de uma economia, política e cultura por partes das potências europeias às populações nativas seria uma forma de colocar aqueles povos no "eixo da civilização". 
Nesse capítulo, o autor analisa o caso da dominação francesa na Argélia, que tem início em 1830 com características pré-imperialistas, mas que no decorrer do século XIX começou a ganhar contornos imperialistas. A entrada francesa no continente africano não começou no século XIX, vem desde o XVII, mas a França foi a segunda principal potência colonizadora em África em finais do Oitocentos.

O autor se atenta para os casos dos impérios russo, otomano e chinês. No caso da Rússia, ela empreendeu uma rápida expansão ao longo do período moderno, mas no século XIX seus interesses se voltaram para a região da Ásia Central. No mesmo momento, o império otomano é visto como um império em decadência e diversas potências europeias têm interesses nas suas áreas. Nem o milenar império chinês escapou das ambições da Europa, em diversos momentos do século XIX, como nas guerras do Ópio e dos Boxers, quando sofreu intervenção motivada por interesses econômicos em seus territórios.

Marc Ferro chama a atenção para o caso da expansão americana. Em diversos momentos do século XIX, os Estados Unidos expandiram seus territórios através de uma política imperialista de dominação e influência sobre países vizinhos (México e Caribe), além da compra de áreas. A política americana de intervenção em outros países começou nesse período e se prolongou no século XX, como demonstrado pelo autor.

No capítulo seguinte, "Indigenização, ocidentalização e coabitação", Marc Ferro apresenta os efeitos do colonialismo na população local e nos colonizadores mostrando os diferentes processos de indigenização e assimilação. $\mathrm{O}$ autor chama a atenção para esses fenômenos na ocupação da América Latina, Argélia e Indochina.

Uma outra característica do processo de colonização europeia no mundo é o trabalho forçado. Marc Ferro percebe que o trabalho forçado ou correcional foi uma das características empregadas pelas potências europeias para a ocidentalização das colônias e uma forma, segundo a mentalidade da época, de colocar os indígenas no caminho da "civilidade". Durante a fase do imperialismo, o trabalho forçado ocupou o espaço deixado pela escravidão.

No quinto capítulo, "Defesa e denúncia", Marc Ferro mostra como os romances e os filmes buscaram retratar o colonialismo. Como meios de grande alcance, eles são carregados de cunho ideológico e acabaram divulgando estereótipos racistas e amenizando as características da colonização. 
A imprensa tem um papel fundamental na criação de apoio da opinião pública nas causas coloniais. Em diversos momentos históricos, a população das potências colonizadoras ajudaram as causas imperialistas de seus países devido a motivações inculcadas pelos jornais e rádios. Entretanto, a imprensa contribuiu com um sentimento anticolonialista durante as descolonizações devido à defesa dos direitos humanos. Ao final do capítulo o autor mostra como o movimento socialista lidou com a colonização e como as lutas de independência foram recebidas na metrópole.

No capítulo seguinte, "As origens das lutas de libertação", Marc Ferro elucida as formas de resistência das sociedades locais. No caso do continente africano, a tradição oral e as religiões africanas foram um instrumento de união para pôr fim ao domínio colonial. As igrejas cristãs apoiaram os movimentos de independência na África, assim o cristianismo foi usado como mecanismo de combate ao colonialismo. Já em outras localidades do mundo, o islamismo e o hinduísmo foram utilizados como meios de emancipação da dominação colonial europeia.

Entender a Segunda Guerra Mundial e suas consequências nos impérios coloniais é fundamental para compreender os processos de descolonização. Marc Ferro mostra que os alemães e os japoneses eram vistos pela população local como libertadores. Entretanto, no decorrer do conflito mundial tanto o Japão quanto a Alemanha empregaram as mesmas formas de colonização que os antigos mandatários coloniais na África e Ásia.

No penúltimo capítulo, "As independências: guerra ou negociação", o autor analisa duas formas da descolonização: através dos conflitos bélicos ou de tratados. Marc Ferro disserta sobre o movimento de independência da Índia, que, de modo pacifista, liderado por Gandhi, trouxe poucos impactos para a ex-potência colonizadora devido à forma de sua condução. Entretanto, o caso indiano é uma exceção para a época. No caso do império colonial francês, diversas guerras foram travadas entre a metrópole com suas ex-colônias, entre elas estão o caso da Argélia e da Indochina, que desencadeou a Guerra do Vietnã (1955-1975). Na África subsaariana francesa o processo de libertação colonial foi negociado.

Os últimos territórios a serem libertados da dominação colonial foram as ex-colônias portuguesas e as antigas repúblicas que compunham a URSS. A independência dos territórios que integravam a União Soviética é a libertação das áreas conquistadas durante o período czarista, de acordo com Marc Ferro. 
No último capítulo, "A herança de hoje", Marc Ferro examina as consequências do colonialismo no mundo atual. Segundo o autor, "nunca a herança da colonização pareceu tão marcante como hoje" (p. 165) como o terrorismo, o racismo, os fluxos migratórios, guerras civis, genocídios e outros dramas cruéis oriundos do período colonial.

Para Marc Ferro, o passado colonial tem sua parcela de responsabilidade nesses processos, porém as forças da globalização acentuam as cicatrizes ainda abertas do colonialismo. A globalização criou novas formas de dominação, uma espécie de "imperialismo multinacional" ou, como a historiografia denomina, de neocolonialismo.

A obra A colonização explicada para todos é um livro ímpar para mostrar que a colonização ainda não é uma página virada na história. O terrorismo, o racismo e o fascismo que voltaram a estar presentes na sociedade do século XXI bebem muito das ideias e consequências do colonialismo. O papel do historiador nesse cenário é buscar compreender esses fatos e dar voz aos outros que foram apagados durante os processos de colonização, os colonizados.

Apesar da falta de um capítulo de conclusão, Marc Ferro apresenta de forma direta e clara as dinâmicas, dilemas e panoramas da colonização em uma perspectiva de longa duração. O livro é recomendado para o grande público por conter uma linguagem objetiva, sucinta e direta. Para os estudiosos sobre colonização a obra se revela uma contribuição fulcral para compreender os impasses do imperialismo e do colonialismo nos dias de hoje.

\section{Referências}

FERRO, M. História das colonizações: das conquistas às independências: séculos XIII a XX. São Paulo: Companhia das Letras, 1996.

FERRO, M. O livro negro do colonialismo. Rio de Janeiro: Ediouro, 2004.

LE GOFF, J. A Europa explicada aos jovens. Lisboa: Gradiva, 2007a.

LE GOFF, J. A Idade Média explicada aos meus filhos. Rio de Janeiro: Agir, 2007b.

VOVELLE, M. A Revolução Francesa explicada à minha neta. São Paulo: Editora Unesp, 2005. 